\title{
Evaluation of Negative Energy Balance in Dairy Cows in Qom Province, and its Relationship with Periparturient Diseases
}

\author{
Mohammad Reza Mohebbi ${ }^{1 *}$, Samad Lotfollahzadeh ${ }^{1}$ and Majid Mohammad Sadegh ${ }^{2}$ \\ ${ }^{1}$ Faculty of Veterinary Medicine, Department of Internal Medicine, University of Tehran, Iran \\ ${ }^{2}$ Assistant professor of theriogenology, Islamic Azad University, Iran
}

Submission: February 01, 2019; Published: February 21, 2019

*Corresponding author: Mohammad Reza Mohebbi, Department of Internal Medicine, Faculty of Veterinary Medicine, University of Tehran, Qareeb Street, Azadi Avenue, Postal Code:1419963111, P.O.Box : 14155-6453, Tehran, Iran

\begin{abstract}
Objective: The aim of this study was to evaluate the correlation between negative energy balance (NEB) and periparturient diseases and to introduce blood BHBA and glucose values as instruments to detect cows with NEB to prevent its harmful effects on immunity and the incidence of periparturient.

Material and Methods: 207 fresh Holstein cows were being investigated over the 2-4 weeks after parturition. BHBA and glucose concentrations were determined, using portable strip test by Optimum Xceed ${ }^{\circledR}$ (Ireland MediSense®Optium), data were evaluated by statistical programs and the results were recorded.

Results: The incidence of NEB in central Iran (with threshold of $1 \mathrm{mmol} / \mathrm{l}$ for serum BHBA values) was $16.3 \%$ that is in range of other reports. Although the incidence of preparturient diseases other than RP was lower than other studies. Serum BHBA values in cows with periparturient diseases were significantly higher than cows with no periparturient diseases. There was no significant correlation between milk production and the values of serum BHBA $(\mathrm{P}<0 / 05)$. Days open and parity were significantly higher in cows with NEB in comparison with cows with no NEB. There was no significant correlation between serum glucose values and periparturient diseases, parity, milk production, and days open ( $p>0 / 05$ ) Keywords: Negative energy balance; Glucose; BHBA; Periparturient diseases
\end{abstract}

\section{Introduction}

Negative energy balance (NEB) is a circumstance occurring in high milk producing fresh cows. It defined as an imbalance between dry matter intake and production needs [1]. After parturition, cows face a sharp increase in production and loss of appetite due to calving stress and high levels of diet change [1]. NEB can be detected by relatively high concentrations of the ketone bodies acetoacetate, $\beta$-hydroxybutyrate (BHBA) and acetone, and a simultaneous low concentration of glucose in the blood [2-4]. The cows decline to mobilization of adipose reserves, and they often lose $60 \%$ or more of their body fat in the first weeks of calving [5,6]. Failure of hepatic gluconeogenesis to compensate energy requirements for milk production and body needs, may be one cause of NEB [7].

The effects of NEB on reproductive system was demonstrated [8]. The period of NAB is accompanied with immunosuppression, periparturient diseases and increased times to first ovulation and first service [9]. The objective of this study was to evaluate the correlation between NEB and periparturient acci dents in dairy cows of Qum province and subsequently to assay the reliability of blood BHBA and glucose values to prevent NEB disorders.

\section{Materials and Methods}

\section{Animal and farm management}

Two hundred-seven fresh Holstein cows were being investigated after parturition in dairy farms of central Iran.

They were selected randomly based on their calving date during September 2010 to May 2011. They were milked twice daily and milk yield was recorded once a week. All information such as parity, date of pregnancy, service to pregnancy ratio, last days open, milk production, etc. were recorded in individual forms for each cow.

\section{Sampling and sample analysis}

Blood samples were collected from all cows in 1-2 weeks after parturition, at least 4 hours after feeding for minimizing 
the effect of feeding on the results. BHBA and glucose concentrations were determined on-farm, using portable strip test by Optium Xceed $₫$ (Ireland MediSense $® O p t i u m$ ), according to the instruction of the producing company. Sensitivity and specificity of the Optium Xceed $®$ has been evaluated $100 \%$ in one study [10], 90\% and $98 \%$ respectively in another study [11].

\section{Statistical analysis}

In this study, SPSS software was used for statistical analysis of the data. One Sample Kolmograv-Smimov test is used to determine the normal distribution of the BHBA and glucose values of blood serum. Kruskal-Wallis and One-way ANOVA tests were used to evaluate the difference between BHBA and glucose in various groups of sick and healthy cows, respectively. The Chisquare test was used to evaluate the distribution of the cows in two groups of normal and high BHBA and glucose levels of the blood samples. Pearson test was also used to evaluate correlation between days open, parity and milk production with BHBA and glucose levels of the blood samples. The two tails level of statistical significance was present at $\mathrm{p} \leq 0.05$.

Table 1: average values of blood serum BHBA and glucose in healthy cows and cows with periparturient diseases.

\begin{tabular}{|c|c|c|c|c|}
\hline Periparturient diseases & Number of cows & Percentage & BHBA values & Glucose values \\
\hline No diseases & 174 & 83.7 & 0.57 & 1.37 \\
\hline RP & 14 & 6.7 & 1.34 & 59.33 \\
\hline Dystocia & 5 & 2.4 & 1.72 & 71.00 \\
\hline RP+ milk fever & 4 & 1.9 & 3.5 & 54.24 \\
\hline Fatty liver & 1 & 0.5 & 1.3 & 57.80 \\
\hline Downer cow syndrome & 1 & 0.5 & 0.56 & 58.34 \\
\hline Mastitis & 3 & 1.4 & 4.5 & 38.77 \\
\hline LDA & 2 & 1 & 4.2 & 52.55 \\
\hline RP+ metritis & 1 & 0.5 & 1.05 & 46.11 \\
\hline Ketosis & 1 & 1 & 1.5 & 73.12 \\
\hline Laminitis & 208 & 0.5 & 0.75 & 63 \\
\hline Total & & 100 & & \\
\hline
\end{tabular}

Table 2: comparison between healthy cows and cows with different periparturient diseases based on the BHBA threshold.

\begin{tabular}{|c|c|c|c|}
\hline Periparturient diseases & $\mathrm{BHBA}<1(\%)$ & $\mathrm{BHBA}>1(\%)$ & Total (\%) \\
\hline No diseases & 76.4 & 7.2 & 83.7 \\
\hline $\mathrm{RP}$ & 2.4 & 4.3 & 6.7 \\
\hline Dystocia & 1.9 & 0.5 & 2.4 \\
\hline $\mathrm{RP}+$ milk fever & 0.9 & 1 & 1.9 \\
\hline Fatty liver & 0 & 0.5 & 0.5 \\
\hline Downer cow syndrome & 0 & 0.5 & 0.5 \\
\hline Mastitis & 1.4 & 0 & 1.4 \\
\hline LDA & 0 & 1 & 1 \\
\hline $\mathrm{RP}+$ metritis & 0 & 0.5 & 0.5 \\
\hline Ketosis & 0.5 & 0.5 & 1 \\
\hline Laminitis & 0 & 0.5 & 0.5 \\
\hline Total & 83.7 & 16.3 & 100 \\
\hline
\end{tabular}

In this study threshold of $1 \mathrm{mmol} / \mathrm{l}$ for serum BHBA is indi-

cated as a cut point of NEB. Healthy cows with no periparturent based on the standard threshold of BHBA (1mmol/l) (24 the)

\section{Results}

Averages of milk production, parity, weight of calves at berth, days open, BHBA, and glucose values of blood serum were $10487 \pm 1090,2.38 \pm 0.8,40.38 \pm 1.04 \mathrm{~kg}, 191.149 .08,0.75 \pm 0.12$ $\mathrm{mmol} / \mathrm{l}$, and $63.96 \pm 4.17 \mathrm{mg} / \mathrm{dl}$, respectively. Averages of milk production, parity, BHBA value, and glucose value in cows with periparturient diseases were as followed: $10458 \pm 382.84 \mathrm{~kg}$, $3.37 \pm 0.49,1.44 \pm 0.42 \mathrm{mmol} / \mathrm{l}$, and $56.26 \pm 10.34$. Averages of the above parameters in healthy cows were $10860 \pm 1477.84$, $2.13 \pm 0.17,0.56 \pm 0.11 \mathrm{mmol} / \mathrm{l}$, and $68.31 \pm 14.41 \mathrm{mg} / \mathrm{dl}$, respectively. Statistical tests indicated that serum BHBA values in cows with periparturient diseases were significantly higher than cows with no periparturient diseases. Table 1 shows the average values of BHBA and glucose in healthy cows and cows with periparturient diseases. Statistical tests indicated the significant difference between serum values of BHBA in healthy cows and cows with periparturent diseases $(p=0.01)$, but the difference between serum values of glucose in healthy cows and cows with periparturient diseases were insignificant $(p>0.05)$. 
and the K-square test showed that the cows with periparturient diseases significantly have the BHBA values higher than 1 mmol/l ( $p<0.05$ ) (Table 2). Totally $57.17 \%$ of cows with NEB, involved with periparturent diseases compared with $6.8 \%$ of cows with no NEB. Comparison between cows with no NEB and cows with NEB, about days open is showed in Table 3 and cows with NEB significantly had the higher days open $(\mathrm{P}<0.5)$. Also, the incidence of NEB was compared with number of parity and the group with NEB had significantly more parity (3.38 parity) than group with no NEB (2.19 parity) (Table 4).

Table 3: comparison between days open in cows with lower and higher than $1 \mathrm{mmol} / \mathrm{l}$ serum BHBA.

\begin{tabular}{|c|c|c|c|}
\hline Groups & $\begin{array}{c}\text { Number of } \\
\text { cows }\end{array}$ & $\begin{array}{c}\text { Per- } \\
\text { centage }\end{array}$ & $\begin{array}{c}\text { Days Open } \\
\text { Mean }\end{array}$ \\
\hline BHBA>1 (cows with NEB) & 29 & 20.7 & 131.5 \\
\hline BHBA<1 (cows with no NEB) & 111 & 79.3 & 93.19 \\
\hline total & 140 & 100 & 101.1 \\
\hline
\end{tabular}

Table 4: comparison between parity in cows with lower and higher than $1 \mathrm{mmol} / \mathrm{l}$ serum BHBA.

\begin{tabular}{|c|c|c|c|}
\hline Groups & $\begin{array}{c}\text { Number of } \\
\text { cows }\end{array}$ & $\begin{array}{c}\text { Per- } \\
\text { centage }\end{array}$ & $\begin{array}{c}\text { Parity } \\
\text { Mean }\end{array}$ \\
\hline BHBA>1 (cows with NEB) & 34 & 16 & 3.38 \\
\hline BHBA<1 (cows with no NEB) & 174 & 83.7 & 2.19 \\
\hline Total & 208 & 100 & 2.38 \\
\hline
\end{tabular}

\section{Discussion}

Duffield introduced two tests to investigate NEB, pre-calving NEFA and post-calving BHBA blood values [12]. In this study, measurement of BHBA and glucose blood values in fresh cows is used to evaluate NEB. Kocako [13] showed the rate of periparturent diseases in fresh cows as: milk fever $7.2 \%$, DA $3.3 \%$, ketosis $3.7 \%$, and RP $9 \%$ [13]. In the current study, incidence of periparturent diseases was recorded as: milk fever1.4\%, DA 1.4 $\%$, clinical ketosis $1 \%$, RP $9.5 \%$, septic metritis $1 \%$, and mastitis $1.4 \%$. All diseases other than RP had the lower incidence in comparison with other studies; however, in one study Tai-Young [14] recorded the incidence of RP $14 \%$ which is higher than current study. The prevalence of subclinical ketosis was reported in wide ranges. Prevalence for increase in BHBA in fresh cows has ranged from 8.9 to $34 \%$ in different studies. In this study, $16.3 \%$ of sampled fresh cows had the BHBA higher than $1 \mathrm{mmol} / \mathrm{l}$ (Table 2).

In most studies, NEB has most correlation with DA [15]. In current study there was a significant relationship between NEB and the incidence of DA, RP, and metritis. It has been demonstrated that the severity and duration of NEB have the positive correlation with the time of first ovulation after calving [16,17]. And, in another study animals with BHBA concentrations $>$ or $=10 \mathrm{mg} /$ $\mathrm{dL}$ had a $13 \%$ decrease in risk of pregnancy [18]. In this study, the correlation between days open and serum BHBA values was calculated. Statistical analysis showed that mean days open in group of cows with BHBA $>1 \mathrm{mmol} / \mathrm{l}$ is 131.5 days and in a group of cows with BHBA $<1 \mathrm{mmol} / \mathrm{l}$ is $93 / 19 \mathrm{mmol} / \mathrm{l}(\mathrm{p}<0.05)$. In two study greater serum BHBA post-calving were associated with less milk yield, greater milk fat percentage, and less milk protein percentage $[18,19]$. But Kaupe $[20]$ indicated that there is a significant positive relationship between BHBA concentration and milk production while the cows with increased BHBA significantly have the higher milk production that can be result in being in the higher risk for ketosis in this group [20].

There was no significant correlation between milk production and the values of serum BHBA $(\mathrm{P}<0 / 05)$. Parity 1 cows mobilized fewer fatty resources than parity 2 and 3 cows [21]. But in another study, there was no meaningful correlation between parity and ketosis [13]. In current study mean parity of cows with BHBA $>1 \mathrm{mmol} / \mathrm{l}$ was 3.38 and of cows with BHBA $<1 \mathrm{mmol} / \mathrm{l}$ was $2.19(\mathrm{p}<0.05)$. Several studies reported that concentrations of plasma glucose and insulin in cows with fatty liver disease were not lower [22,23]. In another study IGF-I (PZ0.001) and glucose (PZ0.001) concentrations, were lower in Sever NEB in comparison with Mild NEB cows [24-26]. In this study mean glucose concentration in cows with $\mathrm{BHBA}>1$ and cows with $\mathrm{BHBA}<1$ was $42.5 \pm 4.72 \mathrm{mg} / \mathrm{dl}$ and $69.46 \pm 3.76 \mathrm{mg} / \mathrm{dl}$ respectively $(\mathrm{p}<0.05)$. But There was no significant correlation between serum glucose values and periparturent diseases, parity, milk production, and days open $(p>0.05)$.

\section{Conclusion}

Based on the findings of this study, measurement of blood BHBA and glucose values are reliable to detect NEB and prevention of periparturient diseases with more emphasis on BHBA. The authors declare that this study is done in the limited geographic area and in limited cow sample size and it needs to be done in larger population considering other involving factors such as dry mater intake before and after parturition.

\section{Acknowledgement}

The authors express their grateful thanks to the Islamic Azad University, Garmsar branch for technical supports.

\section{References}

1. Rossi F, Righi F, Romanelli S, Quarantelli A (2008) Reproductive efficiency of dairy cows under negative energy balance conditions Ann Fac Medic Vet di Parma, XXVIII (173): 180.

2. Duffield T, Sandals D, Leslie KE, Lissemore K, McBride BW (1998) Effect of prepartum administration of monensin in a controlled release capsule on postpartum energy indicators in lactating dairy cows. J Dairy Sci 81: 2354- 2359.

3. Melendez P, Goff JP, Risco CA, Archbald LF, Littell R, (2006) Incidence of subclinical ketosis in cows supplemented with a monensin controlled-release capsule in Holstein cattle, Florida, USA. Preventive Veterinary Medicine 73: 33-42.

4. Ingvartsen KL (2006) Feeding- and management-related diseases in the transition cow: Physiological adaptations around calving and strategies to reduce feeding-related diseases. Anim Feed Sci Technol 126: 175-213.

5. Kadokawa H, Martin BG (2006) A new perspective on Management of reproduction in dairy cows: the need for detailed metabolic information, an improved selection index and extended lactation. J Reprod Dev 52: 161-168. 
6. Renate k, Cernescu h (2009) Effects of negative energy balance on reproduction in dairy cows. lucrări stiinłifice medicină veterinară, xlii: 2 .

7. Herdt TH (2000) Ruminant adaptation to negative energy balance. Influences on the etiology of ketosis and fatty liver. The Veterinary Clinics of North America. Food Animal Practice 6(2): 215-305.

8. Fernandez R, Martini AC, Navarro VM, Castellano JM, Dieguez C, et al. (2006) Novel signals for the integration of energy balance and reproduction. Molecular and Cellular Endocrinology 254(255): 127-132.

9. McGuire MA, Mitchell T, John L, Vicini, Brian C (2004) Controlling Energy Balance in Early Lactation. Advances in Dairy Technology, 16: 241.

10. Kupczynski R, Cupok A (2007) Sensitivity and specify of various tests determinig $\beta$ - hydroxybutyrate acid in diagnosis of ketosis in cows. Electronic Journal of Polish Agricultural Universities 10: 15- 19.

11. Voyvoda H, Erdogan H (2010) Use a hand-held instrument for detecting cows subclinical ketózisának (abstract). Res Vet Sci 89: 344- 351.

12. Duffield T (2000) Subclinical ketosis in lactating dairy cattle: Metabolic disorders of ruminants. Vet Clin North Am Food Anim Pract 16: 231 253

13. Kocako O, Ekiz B (2006) Effects of left displaced abomasum, ketosis and digestive disorders on milk yield in dairy cows. Bulg J Vet Med 9: 273-280.

14. Tai-Young H, Young-Hun J, Seog-Jin K, Chang Yong C (2011) The impact of the duration of retained placenta on postpartum diseases and culling rates in dairy cow. Korean J Vet Res 51: 233-237.

15. Leblanc S, Duffield T (2005) Metabolic predictors of displaced abomasum in dairy cattle. J Dairy Sci 88: 159-170.

16. Patton J, Kenny DA, Mee JF, O’Mara FP, Wathes DC, et al. (2006) Effect of milking frequency and diet on milk production, energy balance and reproduction in dairy cows. J Dairy Science Association 89: 1478-1487.

17. De Vries JM, Veerkamp RF (2000) Energy balance of dairy cattle in relation to milk production variables and fertility. J Dairy Sci 83: 62-69.
18. Ospina PA, Nydam DV, Stokol T, Overton TR (2010) Evelution of non-esterified fatty acids and betahydroxybutirate in transition dairy cattle in the northeastern United States: Critical thresholds for prediction of clinical diseases. J Dairy Sci 93: 546-554

19. Duffield T, Lissemore KD, McBride BW, Leslie KE (2009) Impact of hyperketonemia in early lactation dairy cows on health and production. J Dairy Sci 72: 321- 328.

20. Kauppinen K (1984) Annual milk yield reproduction performance of ketotic and non ketotic cows. Vet Med 31: 694-704.

21. Friggens NC, Berg P, Theilgaard P (2007) Breed and parity effects on energy balance profiles through lactation: Evidence of genetically driven body energy change. J Dairy Sci 90: 5291-5305.

22. Rukkwamsuk T, Wensing T, Geelen MJ (1998) Effect of overfeeding during the dry period on regulation of adipose tissue metabolism in dairy cows during the periparturient period. J Dairy Sci 81(11): 2904 2911.

23. Vanden Top AM, Geelen MJ, Wensing T, Wentink GH, 't-Klooster AT, et al. (1996) Higher postpartum hepatic triacylglycerol concentrations in dairy cows with free rather than restricted access to feed during the dry period are associated with lower activities of hepatic glycerolphosphate acyltransferase. J Nutr 126(1):76-85.

24. Fenwick MA, Llewellyn S, Fitzpatrick R (2008) Negative energy balance in dairy cows is associated with specific changes in IGF-binding protein expression in the oviduct. Reproduction 135: 63-75.

25. Jorritsma R, Wensing Th, Kruip TAM, Noordhuizen JPTM (2003) Metabolic changes during NEB in early lactating cows and effects on fertility. Proceedings of the $10^{\text {th }}$ International Symposium on Veterinary Epidemiology and Economics.

26. Leblance S (2010) Monitoring Metabolic Health of Dairy Cattle in the Transition period. Journal of Reproduction and Development, p. 56.

Your next submission with Juniper Publishers
will reach you the below assets
- Quality Editorial service
- Swift Peer Review
- Reprints availability
- E-prints Service
- Manuscript Podcast for convenient understanding
- Global attainment for your research
- Manuscript accessibility in different formats
( Pdf, E-pub, Full Text, Audio)
- Unceasing customer service
Track the below URL for one-step submission
https://juniperpublishers.com/online-submission.php

